\title{
Pareto Optimality in the work of Pareto
}

\section{Fiorenzo Mornati}

\section{(2) OpenEdition \\ Journals}

Electronic version

URL: http://journals.openedition.org/ress/2517

DOI: $10.4000 /$ ress. 2517

ISSN: 1663-4446

\section{Publisher}

Librairie Droz

\section{Printed version}

Date of publication: 15 December 2013

Number of pages: $65-82$

ISBN: 978-2-600-01805-0

ISSN: 0048-8046

\section{Electronic reference}

Fiorenzo Mornati, «Pareto Optimality in the work of Pareto », Revue européenne des sciences sociales [Online], 51-2 | 2013, Online since 01 January 2017, connection on 19 March 2020. URL : http:// journals.openedition.org/ress/2517 ; DOI : https://doi.org/10.4000/ress.2517 


\section{PARETO OPTIMALITY \\ IN THE WORK OF PARETO}

FIORENZO MORNATI

University of Turin

fiorenzomornati@unito.it

Abstract. This paper reconstructs, in non-formal terms, the development of Vilfredo Pareto's writings on what was to become known as "Pareto optimality". Notably, I rebuild the various versions preceeding the final definition of paretian optimum in economics and I give a few comments on its sociological adaptation.

Keywords: Vilfredo Pareto, ophelimity, utility, Pareto optimality.

Résumé. Cet article retrace, dans des termes non formels, le developpement, dans les écrits de Vilfredo Pareto, du concept que l'on connaît aujourd'hui sous l'appellation d'optimum paretien. Nous rétablissons notamment les différentes versions qui ont précédé la definition finale dudit concept en théorie économique et commentons l'adaptation sociologique qu'en a faite Pareto.

Mots-clés: Vilfredo Pareto, ophelimité, utilité, optimum de Pareto. 
This paper aims at reconstructing, in non-formal terms, the development of Vilfredo Pareto's writings on what was to become known as "Pareto optimality". After some references to the context in which Pareto begun to undertake investigations into welfare economics (I), I shall reveal the early versions of the definition of maximum ophelimity for the society (2). After recounting the first significant academic reactions, by Walras and Wicksell, to Pareto's innovative concept (3), I then elaborate on the development of Pareto's final specification of his economic optimum (4-5). I shall close the paper with a few comments on the sociological adaptation that Pareto made to his economic optimum (6).

Pareto's interest to welfare economics stems from his personal political views, which favoured free trade and liberty in economic, political and social matters more generally. In short, he was motivated to apply the tools of pure economics to demonstrate that a liberal economy is, according to new and non Ricardian criteria, better than an economy in which state intervention plays an important role. However, one of the important, and possibly unexpected, results of his research was to demonstrate that the application of pure economics alone is incapable of establishing the superiority of the liberal economy relative to a socialist economy; a conclusion that Pareto reached more than a decade before Enrico Barone came to the same conclusion in his famous 1908 paper. Among the innovations associated with Pareto's work on welfare issues, there are a number of conceptual and terminological clarifications. Notable in that regard are: the definition of maximum ophelimity for the society in economics'; and, in sociology, the definition of maximum utility for the society (which refers to the utility of the single members of the society) as distinct from maximum utility of the society (which refers to the utility of the society as a whole).

I I recall that from Cours d'Économie politique onwards, Pareto distinguishes between the concepts of ophelimity and utility, applying only the former to his economic reasoning on the societal maximum. In sociology, Pareto uses only the concept of utility. Ophelimity means the ability of a thing to satisfy an individual's need or desire, whilst utility is the ability of a thing to benefit objectively the health or the intellectual development of an individual or the manhood (Pareto, 1964 [1896-1897], t. I, §5). 


\section{I.BACKGROUND AND ASSUMPTIONS}

Before I start to reconstruct the evolution of what would become known as Pareto optimality ${ }^{2}$, it is interesting to make reference to the background of such Paretian investigation.

The first study in which Pareto reflected on the economic properties of freedom (whose proxy is free competition) was an article of I89I, Socialismo e Libertà (1974), where he stated that contemporary society was neither founded on free competition nor on private property. Rather, it was founded on the action that the State carried out in favour of the affluent classes, thus creating a bourgeois socialism (Pareto, 1974 [189I], p.384). Having specified this, he still favours the liberal system on the basis of empirical evidence that presents "freedom as lesser evil" (ibid., p.404).

Around the same time, Pantaleoni and his student Angelo Bertolini accomplished an original attempt of liberal theoretical foundation, in the essay Cenni sul concetto di massimi edonistici individuali e collettivi (I892).

The two authors, who explicitly refer to Edgeworth's Mathematical Psychics (188I), stated that through individual or collective optimal action (that is to say, action performed according to the law of the minimum means), both individual and collective hedonistic maximum could be achieved (Bertolini, Pantaleoni, I892, p.293-294, note I). Individual hedonistic maximum means "the fullest state of well-being" (ibid., p.3or), collective hedonistic maximum means the equitable distribution of goods, if all individuals have the same attitude "towards felicitation" (ibid., p.302). On the contrary, if individuals do not have the same attitude cited above, collective maximum means the unequal distribution of goods that gives more to those who possess this attitude to a greater extent (ibid., p.303). Among the four possible combinations between type of action (individual or collective) and type of resulting maximum (individual or collective), Pantaleoni and Bertolini dwelt mainly on free competition, defined as an "outstanding form of individual work" that enables the achievement of both individual and collective hedonistic maximum (ibid., p.297-298). 
Pantaleoni gave a draft copy of this essay to Pareto. Initially Pareto regarded the hedonistic principle as a stimulus to further epistemological study, such as in the Considerazioni fondamentali sui principi dell'economia politica pura (I892-I893; see Pareto, I984, p.IOI-I02-letter to Pantaleoni of December 6 ${ }^{\text {th }}$, 189I). With regard to Cenni sul concetto..., Pareto merely pointed out that those who knew the collective hedonistic maximum did not necessarily want to accomplish it (ibid., p.99-I00).

But Pareto soon became aware of the Walrasian approach to this issue, that is to say, the competitive general equilibrium which implies, but does not demonstrate, the situation that Pareto shall define as the maximum ophelimity for the society (I894a, p.I49). Pareto immediately noticed that such an approach involved a degree of circularity (1964 [1896-I897], \$65). A theorem, of course, cannot imply its premises: so the Walrasian theorem cannot imply that the private propriety gives rise to the maximum ophelimity for the society as the private property is one of the premises of this theorem. Many years later, Pareto (1968 [1916], §2129') would extend his criticism by agreeing with his student Pierre Boven, who had argued that Walras reasoned in circle when suggesting that maximising behaviour by individuals leads to collective maximisation because he had been inspired by a sentiment favourable to free competition and contrary to monopoly. As demonstrated later in this paper, Pareto escaped this Walrasian circularity by developing an entirely new analysis of collective welfare.

It is finally interesting to note that Pareto highlighted that if on one hand it is not possible to compare interpersonally, and therefore not possible to add the ophelimities of different individuals (1966 [1906], chapter IV, §32), instead it is possible to compare the ophelimities of individuals which do not deviate much from an average type. In a nutshell, Pareto considered the practical possibility of comparing ophelimities that the average man $^{3}$ feels in different conditions, empirically represented by actual individuals who differ very little from such an average man (1964 [1896-I897], volume II, §646). As I shall see infra, Pareto subsequently followed up on the notion of comparability among individuals, 
although by means of a theoretical stratagem in economics and by resorting, in sociology, to a comparison made by the government.

On balance, I believe that Pareto's focus on the issue of maximum ophelimity for society has its origin in two distinct sources: first, from his passion for liberalism; and second, from the attempts by Pantaleoni, Bertolini and Walras to investigate collective welfare, which Pareto found interesting but logically and methodologically unsatisfactory. As a consequence, he set out to develop a new theoretical demonstration of the optimizing property of free competition.

\section{THE FIRST THREE VERSIONS OF PARETIAN OPTIMALITY}

Pareto supplied his first version of Paretian optimality in the article Il massimo di utilità dato dalla libera concorrenza (I894b), which began by recognizing that Walras had shown that free competition maximizes collective ophelimity in the hypothesis of constancy of both prices and production coefficients. While Pareto considered the case of variable consumer prices to be largely irrelevant from a theoretical perspective, he remained of the original view that it is important to study the effect of variations in the production coefficients on economic welfare (ibid., p.48). He undertook his study by starting from Walras's assumption that the production coefficients minimize the cost of production under conditions of free competition (ibid.-quotes Walras, I889, p.32I). Pareto accomplices the minimization of production cost by: envisaging that the prices of the $n$ factors of production $p_{t}, p_{s}$. are constant; obtaining "from the technical conditions of production" the implicit functions that link the n production coefficients of every $m$ goods produced $F_{a}\left(a_{t}, a_{s}, \ldots\right)=0 . .$. ; obtaining from such production functions, that every production coefficient for the production of a good depends on the other n-I (ibid., p.50). All of the above stated, Pareto set out the minimization first order conditions for every equation of the cost of production differentiating it with respect to the n-I production coefficients: therefore the $m(n-I)$ differential equations $p_{t} \partial a_{t} / \partial a_{s}+p_{s}=0 . .$. are obtained. Along with the $m$ production functions, they give rise to a system of $\mathrm{mn}$ equations whose solution creates just as many production coefficients to minimize production costs. 
The first step of this second phase of his demonstration involves the application of the method previously adopted by Walras in his The geometrical theory of the determination of price (I892; ibid., p.50-51). Given the quantities of goods consumed by an individual and the associated prices of those goods, this method facilitates the calculation of the ophelimity that corresponds to the quantity of a numéraire good ${ }^{4}$. By summing all the ophelimities, so determined, of every individual, one obtains the ophelimity which the society made by those individuals benefits from. Similarly, ophelimities that individuals sacrifice to produce goods can be expressed as quantities of a numéraire good.

Pareto does not deal with the exact allocation among individuals of overall ophelimity enjoyed as a result of consumption and sacrificed as a result of production. But he asserts that the ophelimity enjoyed (sacrificed) by every individual is all the greater (lower) the greater (lower) is the overall ophelimity enjoyed (sacrificed). Pareto shows also that if one wants to deliberately alter the distribution of goods produced, it would be more "convenient" (more efficient in a welfare sense) to re-allocate directly the ophelimity from individual to individual than altering the production coefficients of free competition ${ }^{5}$.

That being stated, since the ophelimity by each individual depends on the quantities of goods consumed $r_{a}, r_{b}, r_{c}, \ldots$, an increase in production coefficient $a_{s}$ by da (ibid., p.52) leads to an increase in ophelimity enjoyed by the individual. This increase, when expressed as quantities of the numéraire good a, is given

4 If an individual consumes I $\mathrm{kg}$ of wheat and I $\mathrm{kg}$ of meat, one can say that he benefits directly of the ophelimity of I $\mathrm{kg}$ of wheat and of I $\mathrm{kg}$ of meat. If I $\mathrm{kg}$ of meat exchanges for $2 \mathrm{~kg}$ of wheat, one can say that the individual in question benefits by the ophelimity obtained from the consumption of $3 \mathrm{~kg}$ of wheat: directly from the consumption of I kg of wheat; and indirectly from the consumption of $\mathrm{kg}$ of meat, which may be economically transformed into $2 \mathrm{~kg}$ of wheat (ibid., p.5I).

5 Pareto supplies the following example: the free competition coefficients grant the maximum ophelimity, e.g. 100, which is splitted between Caius (10) and the remainder of the society (90). There are two ways for raising the ophelimity of Caius to 20. The first is that of changing the coefficients, but it does decrease the total ophelimity (e.g. 80) and, so, the ophelimity of the remainder of the society (60). The second is that of conserving the free competition coefficients (and the maximum ophelimity) transferring directly 10 to Caius: in this way, the new ophelimity of the remainder of society (80) is greater than in the first case (ibid., p.5I-52). 
by $\left(\partial \mathrm{r}_{\mathrm{a}} / \partial \mathrm{a}_{\mathrm{s}}+p_{\mathrm{b}} \partial \mathrm{r}_{\mathrm{b}} / \partial \mathrm{a}_{\mathrm{s}}+p_{c} \partial \mathrm{r}_{\mathrm{c}} / \partial \mathrm{a}_{\mathrm{s}}+\ldots\right) \mathrm{d} \mathrm{a}_{\mathrm{s}}{ }^{6}$. The ophelimity enjoyed by the society as a whole depends on the quantities globally consumed of $m$ goods $R_{a}, R_{b}, R_{c}, \ldots$ Consequently, an increase in production coefficient $a_{\mathrm{s}}$ by $\mathrm{d} a_{\mathrm{s}}$, increases by $\left(\partial R_{a} / \partial a_{s}+p_{b} \partial R_{b} / \partial a_{s}+p_{c} \partial R_{c} / \partial a_{s}+\ldots\right) d a_{s}$ the ophelimity for the society expressed in quantities of good a. However, an increase in production coefficient $a_{s}$ also means that ophelimity sacrificed by society increases by $\left(p_{t} \partial R_{t} / \partial a_{s}+p_{s} \partial R_{s} / \partial a_{s}+\ldots\right) d a_{s}$. For society as a whole, welfare is maximised when the positive difference between total ophelimity enjoyed and total ophelimity sacrificed is greatest, which is achieved when the value of $a_{s}$ is conditioned by the maximising requirement that $\partial \mathrm{R}_{a} / \partial \mathrm{a}_{s}+\mathrm{p}_{\mathrm{b}} \partial \mathrm{R}_{\mathrm{b}} / \partial \mathrm{a}_{s}+\mathrm{p}_{\mathrm{c}} \partial \mathrm{R}_{\mathrm{c}} / \partial \mathrm{a}_{\mathrm{s}}+\ldots-\mathrm{p}_{\mathrm{t}} \partial \mathrm{R}_{\mathrm{t}} / \partial \mathrm{a}_{\mathrm{s}}-\mathrm{p}_{\mathrm{s}} \partial \mathrm{R}_{\mathrm{s}} / \partial \mathrm{a}_{\mathrm{s}}-\ldots=0$. Considering also the $\mathrm{m}$ production functions one therefore has a system of $\mathrm{m}(\mathrm{n}-\mathrm{I})+\mathrm{m}=\mathrm{mn}$ equations whose solution determines just as many production coefficients, which maximize the net ophelimity enjoyed by society (ibid., p.54).

The third and last phase of the demonstration consists in checking that the production coefficients determined under conditions of free competition coincide with those maximizing the net ophelimity for society. The demonstration involves differentiating the equations that specify the quantities of every production factor (required to produce the quantity of goods in the collective) with respect to a coefficient of production (ibid., p.55-56).

For instance, when equations $R_{t}=a_{t} R_{a}+b_{t} R_{b}+\ldots ; R_{s}=a_{s} R_{a}+b_{s} R_{b}+\ldots ; \ldots$ are differentiated with respect to $d a_{s}$, one derives equations $\partial R_{t} / \partial a_{s}=R_{a} \partial a_{t} / \partial a_{s}+a_{t} \partial R_{a}$ $/ \partial a_{s}+b_{t} \partial R_{b} / \partial a_{s}+\ldots ; \partial R_{s} / \partial a_{s}=R_{a}+a_{s} \partial R_{a} / \partial a_{s}+b_{s} \partial R_{b} / \partial a_{s}+\ldots$ When these are multiplied respectively by $\mathrm{P}_{\mathrm{t}} \mathrm{p}_{\mathrm{s}}, \cdots$ and recognising that the price of individual goods produced equals the cost of producing them (e.g. $\left.p_{a}=a_{t} p_{t}+a_{s} p_{s}+\ldots\right)$, we obtain the equation $\partial R_{a} / \partial a_{s}+p_{b} \partial R_{b} / \partial a_{s}+\ldots-p_{t} \partial R_{t} / \partial a_{s}-p_{s} \partial R_{s} / \partial a_{s}-\ldots=R_{a}\left(p_{t} \partial a_{t} / \partial a_{s}+p_{s}\right)$.

6 The prices $p_{b^{\prime}} p_{c}, \ldots$ express the quantities of good a necessary to purchase one unit of goods $b, c \ldots$ which makes the addends of the sum in the text homogeneous among them, as expressed all of them in terms of quantity of goods $a$, and, as a consequence, summable. 
As the expression of the second term between parentheses above is equal to zero $^{7}$, this solution is consistent with cost minimising production coefficients and, thereby, maximizes the net ophelimity for the society. However, Pareto also emphasized that coefficients of free competition were not those in force in contemporary society (1964 [1896-I897], §72I). But even more importantly, he stressed that the theorem "can be accepted equally by liberals and socialists", as it relates to production and not to the distribution of goods (I894b, p.6I).

Pantaleoni and Barone informally objected to Pareto's demonstration because he summed the ophelimities of individuals, which were heterogeneous and therefore not capable of summation. Pareto then prepared a revised demonstration of the result (ibid., p.58-60).

Pareto observes that when production coefficient $a_{s}$ varies by $\mathrm{d} a_{s}$, the ophelimity of any consumer varies by $\left(\varphi_{a} \partial \mathrm{r}_{a} / \partial \mathrm{a}_{s}+\varphi_{b} \partial \mathrm{r}_{\mathrm{b}} / \partial \mathrm{a}_{s}+\varphi_{c} \partial \mathrm{r}_{c} / \partial \mathrm{a}_{s}+\ldots\right) \mathrm{d} a_{s}$ which, taking into account the conditions of maximum ophelimity for the individual $\varphi_{b} / \varphi_{a}=p_{b} ; \varphi_{c} / \varphi_{a}=p_{c} \ldots$ can be reformulated as $\left(\partial r_{a} / \partial a_{s}+p_{b} \partial r_{b} / \partial a_{s}+p_{c} \partial r_{c} / \partial a_{s}+\ldots\right) \varphi_{a} d a_{s}$. Such equation must be set to equal zero to meet the first order condition of individual maximum ophelimity. As goods have positive ophelimity, $\varphi_{a}$ has a positive value, so maximisation is predicated on expression between parentheses summing to zero.

However, the number of individuals is $\theta$, so there is a system of $\theta$ equations, but only one unknown quantity to determine (the production coefficient a). Consequently, the system would be over determined if the bracketed term was equal to zero for all individuals. So, in the face of $\mathrm{d}_{\mathrm{s}}$, some individuals may experience a loss in ophelimity as represented by the numéraire good a (a negative value for the term in parenthesis) or a gain in ophelimity (a positive value for the term in parenthesis). Pareto indicated non-zero values for the term in parenthesis with $\lambda$. If all $\lambda$ are positive (negative), all $\lambda \varphi_{\mathrm{a}}$ are positive (negative) which implies that the ophelimity for the collective certainly increases (decreases) and therefore it is advisable to let $a_{s}$ increase (decrease) further. If, however, some $\lambda$ s are positive and other are negative, some individuals would 
benefit from this while others would be disadvantaged. Of course, for different individuals, welfare, $\lambda \varphi_{\mathrm{a}}$, is not comparable because the unit of $\varphi_{a}$, is inconsistent between people. However, as $\varphi_{\mathrm{a}}$ is positive for goods and $\lambda$ is accounted for objectively (as all prices in equation $\partial \mathrm{r}_{a} / \partial \mathrm{a}_{\mathrm{s}}+\mathrm{p}_{\mathrm{b}} \partial \mathrm{r}_{\mathrm{b}} / \partial \mathrm{a}_{\mathrm{s}}+\mathrm{p}_{c} \partial \mathrm{r}_{c} / \partial \mathrm{a}_{\mathrm{s}}+\ldots=\lambda$ are expressed in terms of quantity of good a), Pareto points out that it is still possible for those who gain to economically compensate those who lose as long as the sum of the $\lambda \mathrm{s}^{8}$ is positive. Compensation is no longer possible when the sum of the $\lambda s$ is zero or negative-and variations in a should end when the sum of all $\lambda$ is zero as at that point the ophelimity for the society is maximised.

In his subsequent Cours d'Économie politique (1964 [1896-1897], §385², §72I²), Pareto proposed a new, and clearer, version of the demonstration. He starts from the notion that an individual, thanks to a small increase $d \lambda$ of the quantity of gold at his disposal, can increase quantities of goods consumed and reduce quantities of productive services sacrificed. The subsequent variations of ophelimity are $\mathrm{d} U=\varphi_{\mathrm{a}} \mathrm{dr}+\varphi_{\mathrm{a}} \mathrm{dr}_{\mathrm{b}}+\ldots-\varphi_{\mathrm{s}} \mathrm{dr} \mathrm{r}_{\mathrm{s}} \ldots$, which, when account is taken of the condition for maximising individual ophelimity $\mathrm{p}_{b} / \mathrm{p}_{\mathrm{a}}=\varphi_{\mathrm{b}} / \varphi_{\mathrm{a}} \ldots$ can be reformulated as $d U=\left(p_{a} d_{a}+p_{b} d_{b}+\ldots-p_{s} d_{s}-\ldots\right) \varphi_{a} / p_{a}$ or assuming $\left(p_{a} d_{a}+p_{b} d_{b}+\ldots-p_{s} d_{s}-\ldots\right)=d \lambda$ and $\varphi_{a} / p_{a}=\mu$, as $\mathrm{dU}=\mu \mathrm{d} \lambda$.

As $\varphi_{\mathrm{a}}$ is positive, the sign of $\mathrm{d} U$ depends on the sign of $\mathrm{d} \lambda$. If $\mathrm{d} \lambda$ of all individuals is positive (negative), then $d U$ of all individuals is positive (negative) and the ophelimity for the society increases (decreases). So, if one intends to maximize the ophelimity for the society (which for instance would be the objective of a futuristic socialist state) it is necessary to continue and let the quantities of goods and productive factors vary along the direction (opposite to that) followed so far. As already demonstrated in I894 paper, the maximum ophelimity of society is reached when the sum of $d \lambda$ is zero. In fact, until the sum is positive (negative), by varying the amounts of goods and services along the direction (opposite to that) followed so far, one obtains an additional amount of goods with which one could further increase the ophelimity

8 Which gives the aggregate net value of welfare gains, in terms of good $a$, that result from a change in production coefficients. 
for society. Finally, Pareto showed that one reaches the zero sum of $d \lambda$ also adopting production coefficients that minimize production costs that is to say, adopting free competition coefficients (ibid., §723).

As shown in the next paragraph, Pareto's mathematical skill appealed to Walras. It is interesting to stress the cumbersome but rather clear strategy followed by Pareto in his demonstration. In the first trial, he successively detects the coefficients of free competition, the coefficients maximizing the ophelimity for the society and, at the end, he demonstrates that both correspond. In the second and in the third trial, Pareto, in an innovative way, begins by the variation of the ophelimity of individuals; subsequently he demonstrates that the variations are indirectly homogeneous (due to a clever Walrasian stratagem) and summable. In the end, he finds the maximum ophelimity for the society by using the customary first order condition for maximising a function.

\section{WALRAS AND WICKSELL'S COMMENTS}

The Paretian attempts to identify the conditions for an efficient economic organization of society gave rise to some contemporary comments by Walras and Wicksell.

Walras qualifies Il massimo di utilità dato dalla libera concorrenza as "illuminating". The minimization of production costs, the maximization, with regard to ophelimity, of the functions of demand and supply of services and the indication of "coherence" of both optimization procedures "was undoubtedly the way forward" to attain the demonstration of the optimality of free competition (Walras, 1965, p.605-letter to Pareto of July $9^{\text {th }}$ I894). Nonetheless, Walras adds that he had already given such a demonstration. In that regard, the prices of general equilibrium under free competition, determined through the tâtonnement process, maximize the ophelimities of the owners of production services, whose sum gives the maximum total ophelimity for the society. Therefore, the Paretian demonstration is simply a confirmation of the Walrasian one and of the "excellence of the theory as a whole" (ibid., p.607). But Pareto replies that the Walrasian demonstration is applicable only to the case of fixed production coefficients, 
whereas his own demonstration constitutes a more general treatment because production coefficients are variable. Moreover he aims at indicating, contrary to what was requested by socialists, that there is no greater collective ophelimity than the one "obtained by the game of the entrepreneurs' competition" (Pareto, 1975, p.250-letter to Walras of July 20 ${ }^{\text {th }}$, I894). With specific regard to Pareto's analysis based on $\lambda$, Walras agrees that it represents "a pure creation of political economy" that will enable Pareto to construct a comprehensive applied political economy (Walras, 1965, p.6I I -letter to Pareto of July $25^{\text {th }}$, 1894).

In contrast, Wicksell stressed that trading at prices different from those given by free competition equilibrium could yield advantages that are greater than those achieved at competitive equilibrium prices. Actually, $\varphi$ is the function of total ophelimity of any trader and depends on the available amounts $x$ and $y$ of goods A and B (the first received and the second transferred); the budget constraint is $y=p x$, where $p$ is the price of $A$ (in terms of $B$ ) given under free competition (Wicksell, 1958 [1897], p.I43, note I). If the price increases by $\Delta p$, so that the new price system no longer correspond to that given under free competition, the change in ophelimity may be represented as $\Delta \varphi=(\partial \varphi / \partial x) \Delta x-(\partial \varphi / \partial y) \Delta y=(\partial \varphi / \partial x) \Delta x-(\partial \varphi / \partial y)(p \Delta x+x \Delta p)$ which, after accounting for the condition that the maximum ophelimity for individual traders $\partial \varphi / \partial x=p \partial \varphi / \partial y$, becomes $\Delta \varphi=-(\partial \varphi / \partial y) x \Delta p$. Summing such $\Delta \varphi$ for all traders one obtains $\sum-(\partial \varphi / \partial y) x \Delta p$, which, in general, is not zero. Therefore, Wicksell found that the change in ophelimity might be positive when prices are not those given by free competition. He found that it is only under special circumstances that prices given under free competition will maximize ophelimity, such in the case where all the traders own the same quantities of goods. In fact, according to Wicksell, the economic equality implies that $\partial \varphi / \partial y$ is equal for all the individuals, which transforms $\sum-(\partial \varphi / \partial y) x \Delta p$ into $-(\partial \varphi / \partial y) \Delta p \sum x$ that in free competition, where $\sum x=0$, is cancelled (ibid.).

The agreement between Pareto and Walras on the Paretian demonstration of maximum ophelimity for the society is one of the rare positive episodes in their intellectual relations. However, Pareto does not appear to be aware of the above mentioned Wicksellian criticisms which, as we have 
seen, does not deal with the intricate question of comparability among individual ophelimities and, most of all, aims at destroying the original Paretian support for free competition.

\section{THE PARETO-SCORZA CONTROVERSY}

In 1902, the mathematician Gaetano Scorza (1902a, p.300) stated that "we are still very far from being able to give a mathematical proof of the laissez faire, laissez passer principle". Pareto responded vehemently, stating that the ophelimity maximization condition of individuals represents freedom of exchange, but this alone does not demonstrate maximisation under free competition (Pareto, 1902, p.404). He later reminded that if $\Phi_{1}, \Phi_{2} \ldots$ are total utilities of the individual traders, the change in individuals ophelimity will be positive for some traders and negative for other traders when the original state is defined by the following conditions: $\mathrm{d} \Phi_{1} / \varphi_{\mathrm{Ia}}+\mathrm{d} \Phi_{2} / \varphi_{2 \mathrm{a}}+\ldots=0$ and $\varphi_{\mathrm{Ia}}, \varphi_{2 \mathrm{a}} \ldots$ are positive. It is therefore on this occasion that for the first time Pareto explicitly and formally defined his definitive criterion of maximum of ophelimity for the society (ibid., p.4IO-4I3). Pareto then showed with a long algebraic example (ibid., p.415-420), that this result is achieved when the following conditions are valid: maximum ophelimity of individuals, positivity of degrees of ophelimity of each commodity, and zeroed sum of quantities traded. At this point he underlined that these conditions subsisting in case of free competition, this latter "leads to" maximum ophelimity for society (ibid., p.420). This maximum is described geometrically by the point of tangency between two indifference curves (one for each trader). There is anyhow a locus of ophelimity maxima upon every point one reaches, either through free competition (defined as the organization where prices are constant) or through "other different regulations, provided that they are duly selected", for instance "a tyrant who compelled those who barter to get the same results as free competition" (ibid., p.42I-422, p.43I). As I shall see in the following paragraphs, Pareto largely restricted himself to repeat, in his future works, the results obtained in this paper, although with some additions and clarifications. 


\section{PARETIAN OPTIMALITY IN THE MANUEL D'ÉCONOMIE POLITIQUE}

In his Manuel d'Économie politique (1966 [1906]) Pareto envisages the maximum of ophelimity for the society as a property of the general economic equilibrium and he defines it as the position from which any small variation increases the ophelimity of some and reduces the ophelimity of others (ibid., chapter VI, §32-33). Being $\Phi_{1}, \Phi_{2}, \ldots \Phi_{\mathrm{n}}$ the total ophelimities of the $\mathrm{n}$ individuals; $\delta$ all "the variations [...] that are compatible with the constraints of the system” (ibid., appendix, §89); $\varphi_{10^{\prime}} \varphi_{20} \ldots \varphi_{\text {na }}$ the marginal ophelimities of good a for each individual; $\delta \Phi / \varphi_{a}=\delta q_{a}$ the variation of the quantity of good a owned by anyone among $\mathrm{n}$ individuals, with such quantities that, it is explicitly said, are therefore homogeneous among them and summable (ibid., §ı 27-I 29). He therefore maintains the formal definition of maximum ophelimity already found in the controversy with Scorza, specifying that it implies that $\delta \Phi$ are nil, for some individuals, positive, for other individuals, and negative for others (ibid., §89). Similarly Pareto, for the case in which traders accept market prices, restates that if equilibrium takes place in a point of tangency between indifference curves, the society benefits of the maximum ophelimity: in fact if one shifts from such point, the ophelimity of a trader increases, while the other one decreases (ibid., chapter VI, §34-35, §43) ${ }^{10}$.

Further studying the results of 1902, Pareto highlights that if the sales revenues of a commodity are greater than its total production cost (as in the case of monopoly), this positive difference could be spread among members of society, which implies that the $\delta \Phi$ of beneficiaries are positive (those of the remaining members of society being zero) and that, therefore, $\delta \Phi_{\mathrm{I}} / \varphi_{\mathrm{Ia}}+\delta \Phi_{2} / \varphi_{2 a}+\ldots+\delta \Phi_{\mathrm{n}} / \varphi_{\mathrm{na}}>0$.

10 Pareto shows that instead from a point of intersection among indifference curves (a situation which represents a equilibrium in monopoly, as one of the two traders is able to manipulate the price of the commodity) one can move away making the ophelimity increase or decrease of both traders: therefore when equilibrium is obtained under conditions of monopoly, society does not attain maximum ophelimity (ibid., §36). 
The maximum of ophelimity for society is obtained when (i) total revenues equal total costs and (ii) prices reflect marginal costs (ibid., appendix §9o, §92). This double condition is not met by free competition in the important case where prices are constant and there are positive fixed costs (ibid., §92). Actually it would need to have consumers pay a fixed amount for a commodity, selling them later the units of commodities at their marginal costs (ibid., chapter VI, $\S 45-48, \S 58$ ): the private firms (and therefore free competition) cannot do it whilst collectivism can do it.

So, Pareto's conclusion remains in contradiction with the liberal passion, which had been at the origin of his interest for the maximum ophelimity for the society. In order to achieve the maximum ophelimity for the society, pure economics does not enable us to say whether it is preferable for the economy to be based on private property and free competition or on a collectivist one (ibid., §60-6I).

\section{MAXIMUM UTILITY IN SOCIOLOGY}

In view of the impossibility of comparing the ophelimities of individuals, in economics there can only be a maximum ophelimity for the society (that, as I have discussed amply above, takes into account the only variations of the individuals' ophelimities) and not the maximum ophelimity of the society (which should precisely consider the ophelimity of society taken as a whole).

But in sociology, however, Pareto relaxes this restriction and allows for interpersonal subjective comparisons, albeit with reference to sentiments. Therefore, in sociology there are the maximum utility for the society and maximum utility of the society (Pareto, I968 [1916], §2133-213). By way of example, a situation of prosperity with strong national income inequality may be an example of a maximum utility of the society while a situation involving a weaker national income and less inequality in the distribution of income might be an example of maximum utility for the society, based on subjective interpersonal comparisons (ibid., §2135). 
More formally, in Pareto's sociological treatment of collective welfare, one should look for positive quantities $\alpha_{1}, \alpha_{2}, \ldots$ (each one of them assigned to every member of the society) that enable to get to the equation $\alpha_{1} \delta \Phi_{1}+\alpha_{2} \delta \Phi_{2}+\ldots=0$ (Pareto, I9I3, p.339). The amounts $\alpha_{1}, \alpha_{2}, \ldots$ are subjectively assigned welfare weights for individuals I, 2 and so on: for instance a humanitarian may assign high $\alpha$ to himself (e.g. individual I) and to the criminals he supports (e.g. individual 2) but a very low $\alpha$ to the victims of crime (ibid., p.340). This process is then repeated for each member of the society, so there is a system of the equations $\alpha_{1} \delta \Phi_{1}+\alpha_{2} \delta \Phi_{2}+\ldots=0$, one for each member of the society. However, the equations for each individual are still heterogeneous. To reduce this system of equations to a single homogeneous social welfare relationship, the assigned weighting $\alpha$ of the various equations are multiplied by $\beta^{1}, \beta^{2}$, which are politically allocated values "determined in view of an objective end [...] for instance, the prosperity of the community"(ibid.). This work of homogenization might be accomplished by the government. If, for instance, they considered that "it is necessary, for the prosperity of the community, to punish criminals", the government shall attribute low $\beta$ to the equations of humanitarians and criminals and high $\beta$ to those of their victims (ibid.). Thus the individual equations of individual assessment $\alpha_{1}^{1} \delta \Phi_{1}+\alpha_{2}^{1} \delta \Phi_{2}+\ldots=0, \alpha_{1}^{2} \delta \Phi_{1}+\alpha_{2}{ }_{2} \delta \Phi_{2}+\ldots=0 . . .{ }^{11}$ are transformed into the following homogeneous ones, $\beta^{1}\left(\alpha_{1}^{1} \delta \Phi_{1}+\alpha_{2}^{1} \delta \Phi_{2}+\ldots\right)=0$, $\beta^{2}\left(\alpha_{1}^{2} \delta \Phi_{1}+\alpha_{2}^{2} \delta \Phi_{2}+\ldots\right)=0 . .{ }^{12}$. These latter equations, once summed, lead to the equation $\left(\beta^{\mathrm{1}} \alpha^{1}+\beta^{2} \alpha^{2}+\ldots\right) \delta \Phi_{1}+\left(\beta^{1} \alpha_{2}^{1}+\beta^{2} \alpha_{2}^{2}+\ldots\right) \delta \Phi_{2}+\ldots=0$, that can be reformulated as $\mathrm{M}_{\mathrm{I}} \delta \Phi_{\mathrm{I}}+\mathrm{M}_{2} \delta \Phi_{2}+\ldots=\mathrm{O}^{13}$ similar to the known $\delta \Phi_{\mathrm{I}} / \varphi_{\mathrm{Ia}}+\delta \Phi_{2} / \varphi_{2 \mathrm{a}}+\ldots=0$. The government that aims at the maximum utility of the society as a whole, shall not exceed the situation corresponding to the condition $\mathrm{M}_{1} \delta \Phi_{\mathrm{I}}+\mathrm{M}_{2} \delta \Phi_{2}+\ldots=\mathrm{O}$ as if he did it, one would contradict himself "sacrificing those who were not to be sacri-

II The first expresses the evaluations that I gives of the utility variations of every individual, the second expresses similar evaluations of 2 , etc.

$12 \beta^{l}\left(\alpha_{1}^{l} \delta \Phi_{1}+\alpha_{2}^{l} \delta \Phi_{2}+\ldots\right)=0$ represents the evaluation that the government gives to the evaluations that individual I gives of the utility variations of himself, of individual 2, etc.

13 Where $M_{1}$ represents the sum of the evaluations that the government provides of the evaluations that individuals I, $2 \ldots$ give of the individual I utility variation, etc. 
ficed”. In fact in a sub-optimal situation, the individuals protected by the government would be in a worse situation than in an optimal situation (ibid., p.34I).

There is no space in the present paper to investigate the relationship between economics and sociology in Pareto's thought. However, a few observations on the issue can be made. Based on a study of Pareto's entire scientific output, one can venture the idea that Pareto was neither an economist nor a sociologist; rather, he remained always a social scientist. His interests focussed, over and over again, on economics or on sociology due to his temporary moods and, most of all, due to his teaching load: the Cours d'Économie politique (1964 [1896-1897]) and the Systèmes socialistes (1965 [190I-1902]) are the outgrowth of long series of lectures. Surely, over time, the underlying schema of equilibrium, if often interwoven and refined, unified Pareto's treatment of economic and sociological issues. Finally Pareto's economics is the study of economic equilibrium whilst Pareto's sociology is the study of social equilibrium. The concepts of economic and sociological maxima support the above thesis to Pareto's complementary approach to economics and sociology.

\section{CONCLUSION}

Pareto began to deal with the maximum ophelimity for the society in the I890 when he was driven by an enduring passion for economic liberalism and a dissatisfaction with the way Pantaleoni, Bertolini and Walras had dealt with the topic. This paper has attempted to conceptually reconstruct Pareto's various efforts to define the conditions for optimality. Initially he successively equated optimality, as a maximum of ophelimity for the society, with production coefficients obtained under free competition (those which minimize production cost). But following the critics by Pantaleoni and Barone, Pareto alters his demonstration strategy by gradually reaching the definition of maximum as a situation in which movement away from a point would advantage someone, but disadvantage someone else. To reach this result, taking into account that in economics, individual ophelimities are not comparable, Pareto in various manners makes use of the stratagem borrowed from Walras, to transform the 
individual ophelimities variations into comparable quantity variations of the same commodity. So, Pareto defines the maximum by using the customary first order conditions for maximising a function. In a well-known article of 1902 and in the Manuel d'Économie politique, Pareto develops the formal presentation of what was to become universally known as a Pareto optimum. Moreover he provides a geometrical representation of his results. But, it is very important to stress too that in the Manuel d'Économie politique Pareto finds that pure economics is unable to establish whether free competition or collectivism is the best form of economic organization from the point of view of reaching the maximum ophelimity for the society.

Finally, while Pareto's economic analysis of optimality avoids interpersonal comparisons of welfare, he retreats from that position in sociology. Pareto's sociology recognises that people do make interpersonal comparisons. In view of this, he considers how social welfare might be logically maximised if we account for the fact that individuals, and governments, frequently use subjective sentiments to assess their own welfare and the welfare of other members of the society. As a result, Pareto elaborates new notions, different from the maximum ophelimity for the society but complementary to it, of maximum utility for and of the society.

AN. I thank Pascal Bridel and Michael McLure for their comments. The remaining errors are of mine.

\section{BIBLIOGRAPHY}

BERTOLINI A., PANTALEONI M., I892, "Cenni sul concetto di massimi edonistici individuali e collettivi", Giornale degli Economisti, aprile, p.285-323.

MCLURE M., 2000, "The Pareto-Scorza Polemic on Collective Economic Welfare", Australian Economic Papers, p.347-37l.

MONTESANO A., 199I, II massimo di ofelimità per la collettività: definizioni, analisi, interpretazioni di Pareto e loro generalizzazione, in Pareto oggi, G. Busino (ed.), Bologna, II Mulino, p. II5-138. 
PARETO V., 1894a, "Teoria matematica dei cambi forestieri", Giornale degli Economisti, febrario, p.142-173.

-, I894b, "II massimo di utilità dato dalla libera concorrenza", Giornale degli Economisti, luglio, p.48-66.

-, 1902, "Di un nuovo errore nello interpretare le teorie dell'economia matematica", Giornale degli Economisti, novembre, p.40I-433.

-, 1913, "Il massimo di una utilità per una collettività in sociologia", Giornale degli Economisti, aprile, p.338-34I.

-, 1964 (1896-1897), Cours d'Économie politique, Furres complètes, t. I-II, Genève, Droz.

-, 1965 (1901-1902), Les Systèmes socialistes, Fuvres complètes, t.V Genève, Droz.

-, 1966 (1906), Manuel d'Économie politique, Euvres complètes, t. VII, Genève, Droz.

-, 1968 (1916), Traité de sociologie générale, Euvres complètes, t.XII, Genève, Droz.

-, 1974 (I89I), "Socialismo e Libertà", in Écrits politiques, vol. I, Lo sviluppo del capitalismo, Euvres complètes, t.XVIII, Genève, Droz, p.376-409.

-, 1975, Correspondance: 1890-1923, Fuvres complètes, t.XIX, Genève, Droz.

-, 1984, Lettere a Maffeo Pantaleoni (1890-1923), Fuvres complètes, t.XXVIII, Genève, Droz.

-, 1989 (19II), Statistique et Économie mathématique, Euvres complètes, t.VIII, Genève, Droz, p.319-368.

SCORZA G., 1902a, "Osservazioni sulla teoria del baratto secondo il prof. Walras", Giornale degli Economisti, marzo, p.282-302.

-, 1902b, "[Review by G. Cassel], Grundriss einer elementaren Preislehre", Giornale degli Economisti, agosto, p.191-194.

WALRAS L., I889, Éléments d'économie politique pure ou théorie de la richesse sociale, Lausanne, Rouge.

-, 1965, Correspondence of Léon Walras and Related Papers, vol.II, 1884-1897, Amsterdam, North-Holland Publishing Company.

WICKSELL K., 1958 (1897), "Vilfredo Pareto's Cours d'Économie politique", in Selected Papers on economic theory, London, Allen and Unwin, p. I4I-I5I. 